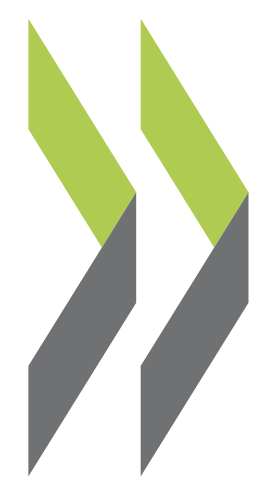

OECD Economics Department Working Papers No. 829

\title{
Improving Fiscal Performance Through Fiscal Councils
} Robert P. Hagemann 
Organisation de Coopération et de Développement Économiques

Organisation for Economic Co-operation and Development

10-Dec-2010

ECONOMICS DEPARTMENT

English - Or. English

Cancels \& replaces the same document of 09 December 2010

IMPROVING FISCAL PERFORMANCE THROUGH FISCAL COUNCILS

ECONOMICS DEPARTMENT WORKING PAPERS No. 829

By Robert Hagemann

All Economics Department Working Papers are available through OECD's internet web site at www.oecd.org/Working_Papers

JT03294265

Document complet disponible sur OLIS dans son format d'origine

Complete document available on OLIS in its original format 


\section{ABSTRACT/RÉSUMÉ \\ Improving fiscal performance through fiscal councils}

There is growing interest in the role of independent fiscal institutions, or fiscal councils, in helping to improve fiscal performance. This paper provides some guidance on the scope for improving fiscal performance through fiscal councils based on the available literature and the range of fiscal institutions in the OECD countries. The effectiveness of fiscal councils hinges on several factors, including having full autonomy within the scope of their mandates, active and unfettered dissemination of their analysis and their credibility. Experience and empirical evidence suggest that delegating macroeconomic forecasting to an independent fiscal council can indeed reduce forecasting bias. There is some empirical evidence that independent fiscal institutions can buttress a government's capacity to comply with a numerical rule. Good fiscal institutions are a necessary condition for achieving disciplined fiscal performance. Experience demonstrates, however, that their existence is not sufficient. Without strong and sustained political commitment to a medium-term fiscal goal and, where relevant, to the mandate of a fiscal council, durable improvements in fiscal performance will remain elusive.

This working paper relates to the 2010 OECD Economic Survey of the Euro Area (www.oecd.org/eco/surveys/euroarea).

JEL classification: H61

Keywords: fiscal policy; fiscal councils; fiscal frameworks

$* * * * * * * * * * * * * * * * * * * * * * * * * * * * * * *$

\section{Améliorer la performance budgétaire à travers des conseils budgétaires}

Un intérêt croissant est accordé au rôle des institutions budgétaires indépendantes, ou conseils budgétaires, pour contribuer à l'amélioration des résultats budgétaires. Ce document fournit quelques indications sur la possibilité d'améliorer ces résultats par le biais des conseils budgétaires, en se basant sur la littérature existante et sur la gamme des institutions budgétaires dans les pays de l'OCDE. L'efficacité des conseils budgétaires dépend de plusieurs facteurs, notamment de leur entière indépendance dans l'exercice de leur mandat, d'une communication active et sans restrictions de leurs analyses et de leur crédibilité. L'expérience et les données empiriques montrent que déléguer les prévisions macroéconomiques à un conseil budgétaire indépendant peut effectivement réduire les erreurs de prévision. Selon les données empiriques, les institutions budgétaires indépendantes peuvent étayer la capacité d'un gouvernement à respecter une règle numérique. De bonnes institutions budgétaires sont une condition nécessaire pour la discipline budgétaire. Toutefois, l'expérience montre que leur existence ne suffit pas. Sans un engagement politique fort et durable envers un objectif budgétaire à moyen terme et, le cas échéant, envers le mandat d'un conseil budgétaire, des améliorations pérennes de la performance budgétaire resteront illusoires.

Ce document de travail a été réalisé dans le cadre de l'Étude économique de la Zone euro 2010.

(www.oecd.org/eco/etudes/zoneeuro).

Classification JEL : H61

Mots clés: politique budgétaire, conseil budgétaires, institutions budgétaires

Copyright OECD 2010

Application for permission to reproduce or translate all, or part of, this material should be made to: Head of Publications Service, OECD, 2 rue André-Pascal, 75775 Paris Cedex 16, France 


\section{TABLE OF CONTENTS}

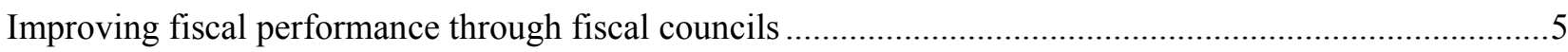

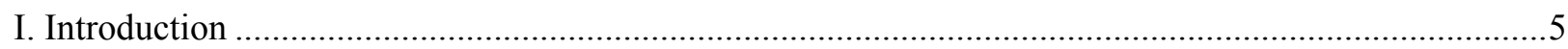

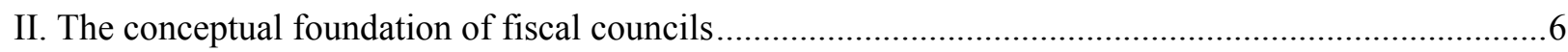

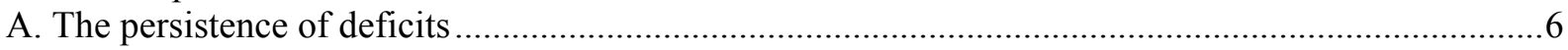

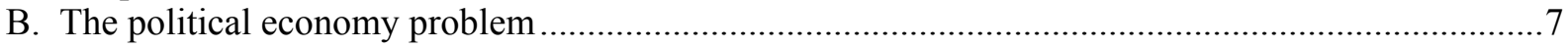

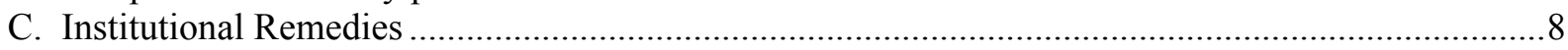

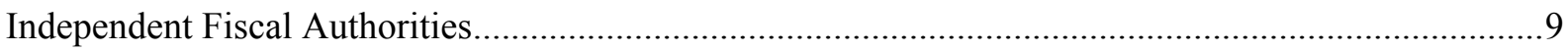

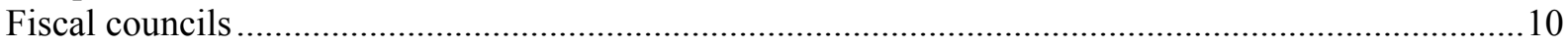

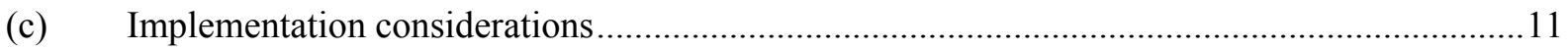

III. Experience with fiscal councils ……...................................................................................

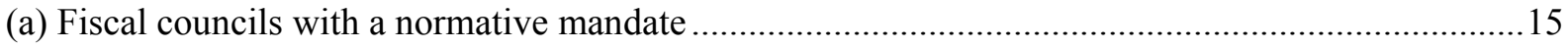

(b) Fiscal councils providing independent analysis of fiscal issues ..............................................16

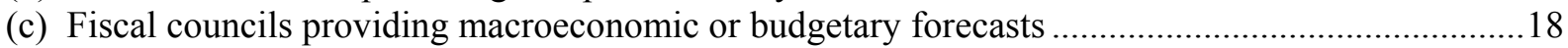

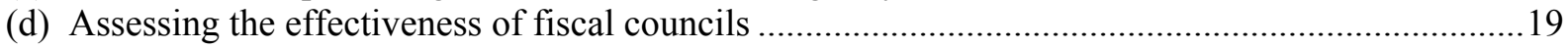

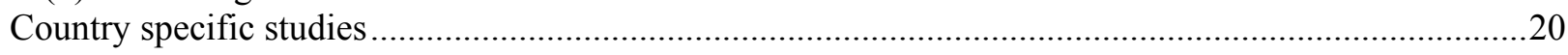

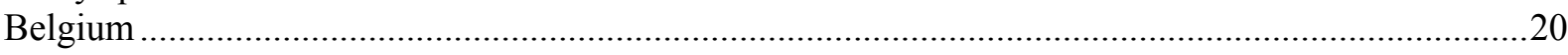

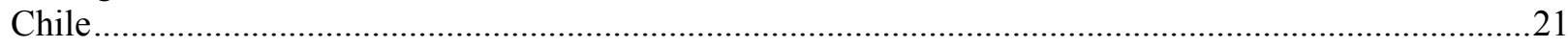

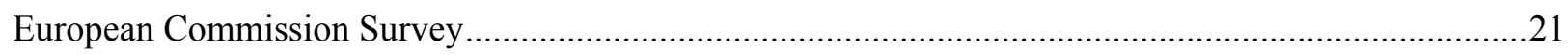

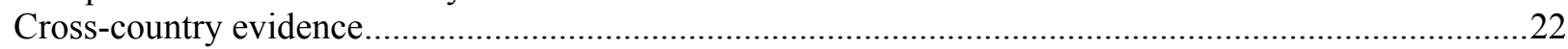

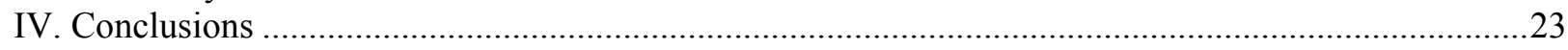

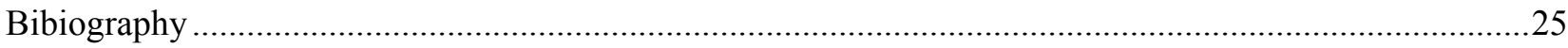

\section{Tables}

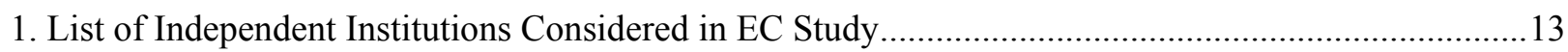

1. List of Independent Institutions Considered in EC Study (Cont.) ......................................................14

\section{Figures}

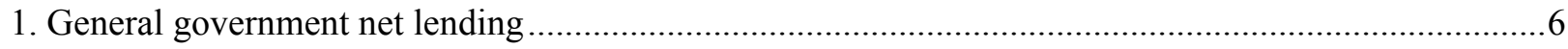

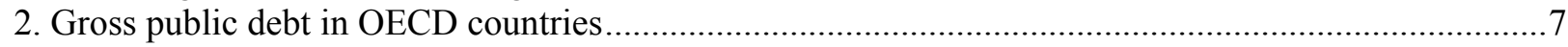

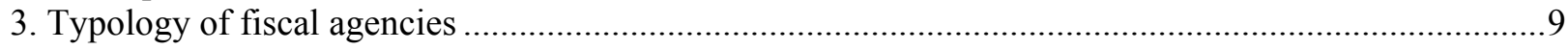

4. Budgetary developments and fiscal councils ...............................................................................22

5. Potential channels of impact of fiscal councils and relationship between fiscal councils and fiscal rules 23

\section{Boxes}

Box 1. Canada's Parliamentary Budget Officer. .17

Box 2. The Central Planning Bureau of the Netherlands...................................................................... 18 
ECO/WKP(2010)85 
ECO/WKP(2010)85

\title{
Improving fiscal performance through fiscal councils
}

\author{
Robert Hagemann ${ }^{1}$
}

\section{Introduction}

There is growing interest in the role of independent fiscal institutions, or fiscal councils, in helping to improve fiscal performance. At its most basic level, a fiscal council is a publicly funded entity staffed by non-elected professionals mandated to provide non-partisan oversight of fiscal performance and/or advice and guidance - from either a positive or normative perspective - on key aspects of fiscal policy. The increased interest is found not only in academic circles and international organisations, but among governments as well. In the past 4 years alone, new institutions have been established in Canada, Hungary, Sweden, and the United Kingdom. As countries begin to grapple with the delicate challenge of consolidating the seriously deteriorated fiscal positions stemming from the recent crisis, their search for institutional reforms that can deliver fiscal results and provide political cover may well lead to the establishment of yet more fiscal councils.

A fiscal council can contribute to improved fiscal performance in a variety of ways, but it is no "silver bullet" for securing and maintaining fiscal discipline. By depoliticising various aspects of fiscal policy, whether related to formulation or monitoring, fiscal councils can better inform voters on the actual state of fiscal policy and raise the political costs of fiscal indiscipline. There is increasing - albeit still limited empirical evidence that the presence of fiscal councils can contribute to better fiscal outcomes. At the same time, there remains some uncertainty over the direction of causation. A fiscally responsible government may wish to create a fiscal council to solidify the credibility it has already gained. Conversely, absent political will, there are no assurances that a new institution such as a fiscal council will help. As von Hagen (2010) notes in regard to the role of fiscal councils in strengthening a rules-based fiscal framework: "Fiscal councils may be helpful to strengthen the credibility of medium-term fiscal rules, but only in cases where the government has considerable commitment power to begin with." Thus, a fiscal council could be either superfluous where strong political commitment is present, or ineffective where it is not.

The purpose of this paper is to provide some guidance on the scope for improving fiscal performance through fiscal councils. This paper synthesises the available literature on independent fiscal institutions. Section II provides a short overview of the principal issues at play, both in terms of the reasons for considering the introduction of a fiscal council (or strengthening existing ones) and key institutional considerations. Section III provides information on the range of fiscal institutions in the OECD (without pretence of universal coverage) to draw lessons from their experiences. Section IV offers conclusions.

1. Independent consultant to the OECD Economics Department. The views expressed are those of the author and should not be interpreted as representing those of the OECD or its member governments. The author wishes to thank Robert Chote (UK Office of Budget and Responsibility), George Kopits (Fiscal Council of Hungary), and Sebastian Barnes and his colleagues in the OECD Economics Department for helpful comments on an earlier draft. He also wishes to thank Isabelle Duong for statistical assistance and Deirdre Claassen for technical preparation. This document was finalised before recent reforms to the Fiscal Council of Hungary. 


\section{The conceptual foundation of fiscal councils}

\section{A. The persistence of deficits}

Budgetary discipline requires that governments maintain fiscal positions that foster macroeconomic stability and sustainable growth. This in turn calls for counter-cyclical fiscal stances to help smooth output fluctuations, calibrated with sufficient vigilance to ensure symmetric budgetary impacts over the cycle to avoid an excessive accumulation of public debt. A prudent stance would also allow for the build-up of fiscal cushions to enable governments to respond to unexpected shocks over the medium term and anticipated pressures over the long term, such as implied by population ageing (Heller, 2003; and Kumar and Ter-Minassian, 2007). The overall record in the OECD over the past several decades, however, largely reflects a much more lacklustre record of sustained high deficits and a widespread tendency to adopt and implement pro-cyclical fiscal positions, resulting in high levels of public debt.

Figure 1. General government net lending

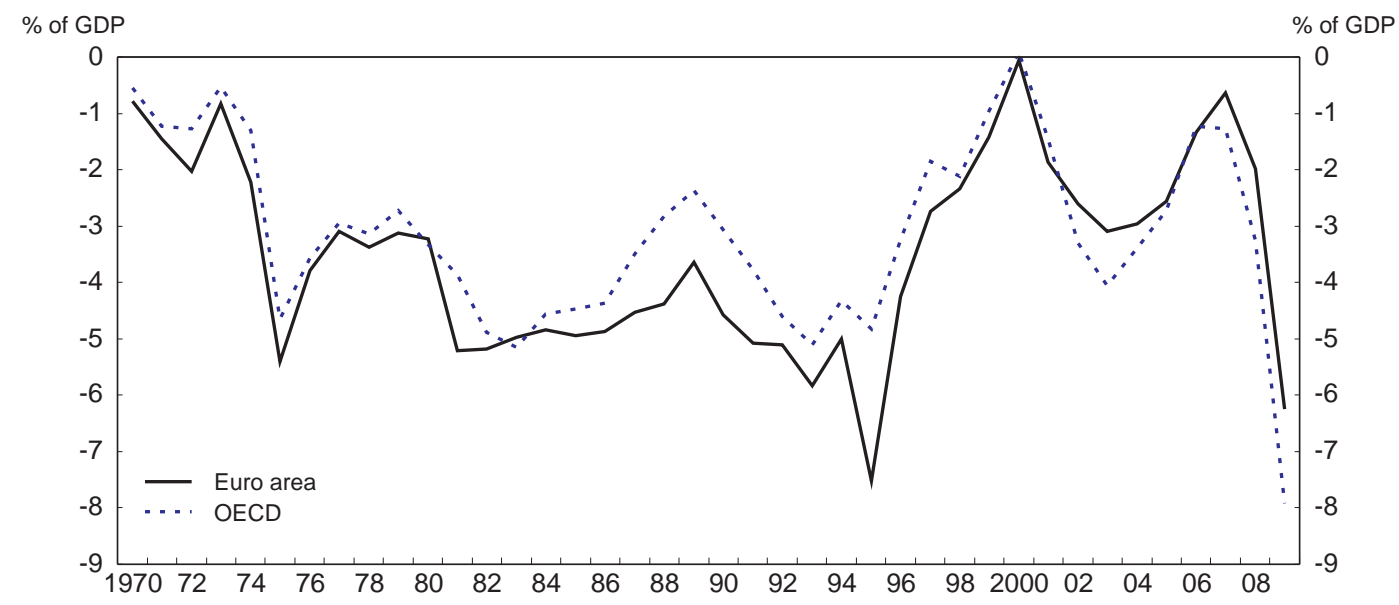

Source: OECD, OECD Economic Outlook 88 database.

Deficits have clearly been the norm throughout most of the industrialised world during the past several decades. The overall fiscal balance of OECD economies, as well as in the large majority of its member countries, was in deficit throughout virtually the entire three decades to 2007 (Figure 1). A number of countries, however, have achieved sustained fiscal consolidations, noticeably lowering public indebtedness. Still, in many countries, deficits have been accompanied by sustained high levels public debt (Figure 2), leaving inadequate fiscal cushions to comfortably respond to the financial crisis. In turn, public debt has now reached post-World War II record levels in many cases. It is widely recognised that sustained high deficits over such long periods can be harmful to long-run economic growth and are incompatible with optimal fiscal strategies, such as tax smoothing. Deficit bias is thus problematic.

There is ample evidence that deficit bias is accompanied by pro-cyclicality bias as well. Although there are wide differences across regions and countries in the strength of automatic stabilisers, the cyclical movements of budget balances in general appear to be smaller than would result from the operation of the automatic stabilisers alone, implying a tendency toward offsetting discretionary policies (Balassone and Kumar, 2007). For instance, for industrial countries, on average, a $0.3 \%$ of GDP improvement in the overall nominal budget balance accompanies a one-percentage point of GDP increase in actual relative to potential output. Set against a larger actual average budgetary impact of automatic stabilisers of around $1 / 2$ per cent of GDP (van den Noord, 2000; Bouthevillain et al., 2001; and IMF, 2004), discretionary policies appear to result in a pro-cyclical fiscal stance. Moreover, the tendency toward pro-cyclicality is asymmetric, whereby discretionary policies offset the effects of automatic stabilisers during upturns but not during economic downturns (Balassone and Kumar, 2004). 
Figure 2. Gross public debt in OECD countries

As a percentage of GDP, 1990-2009
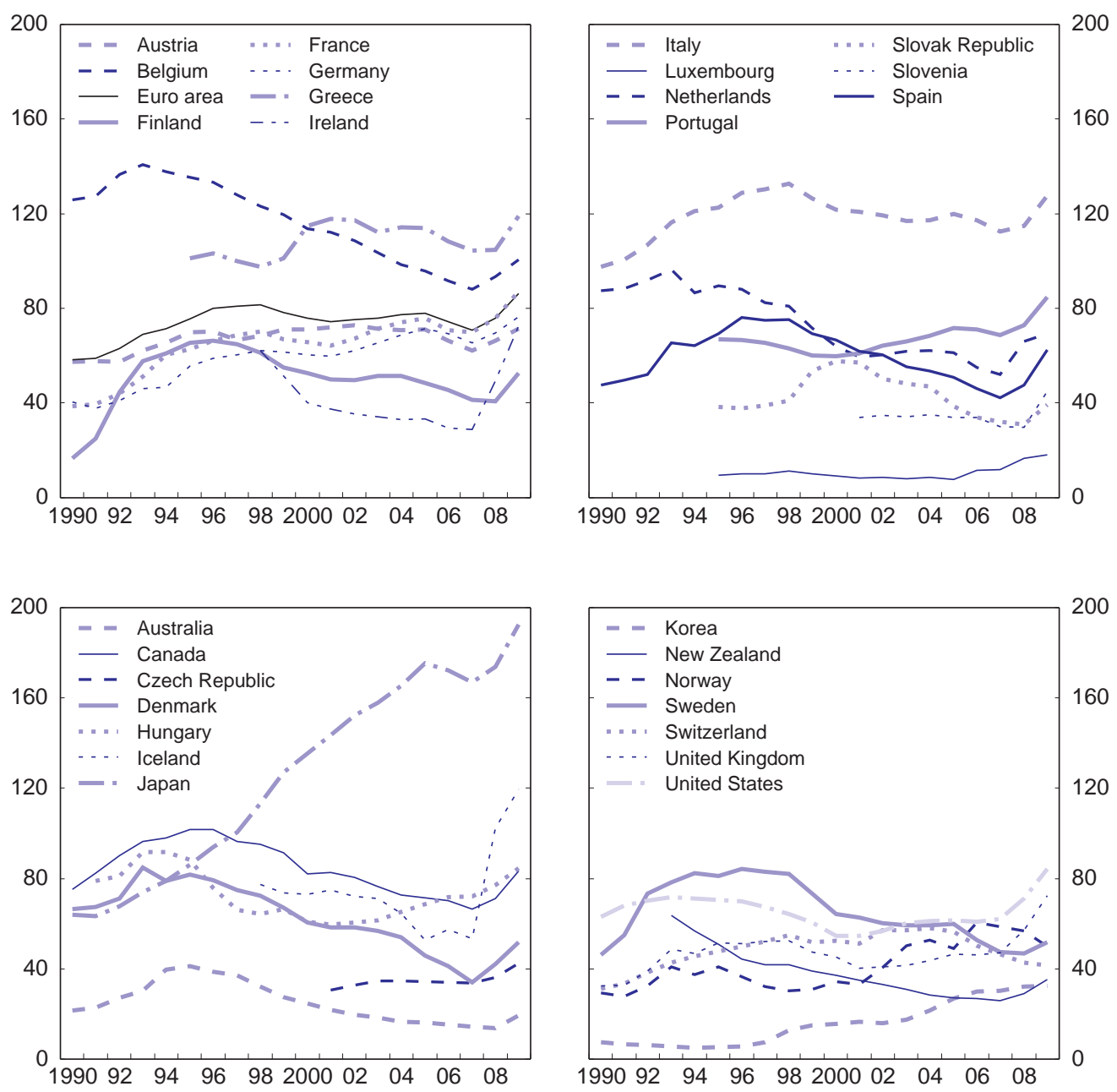

Source: OECD, OECD Economic Outlook database.

\section{B. The political economy problem}

The persistence of deficits over so long a period in so many countries suggests that factors other than economic conditions are at play. Nordhaus (1975) was among the first to posit a strong relationship between public spending and the political cycle. Researchers have since focused increasingly on the interplay of political motivations on the one hand and accommodating budgetary practices and institutions on the other hand as a potentially key determinant of deficit bias (Poterba and von Hagen, 1999).

Political economy considerations are now widely recognised as crucial to understanding the deficitand pro-cyclicality bias in fiscal policy. Several explanations are prominent in the literature. First, the deficit bias is related to the short sightedness and selfishness of policymakers who initiate deficitaugmenting spending or tax-cutting programs in the interest of re-election (Persson and Svensson, 1989; and Alesina and Tabellini, 1990). Policymakers' myopia is rooted in electoral uncertainty, which weakens their concern about the implications for future tax increases or expenditure cuts of their politically motivated deficit-increasing favours. In turn, the fiscal behaviour of incumbent legislators will lead to higher deficits than desired by voters (Rogoff, 1990). This behaviour is facilitated by budgetary opacity that masks the fiscal truth, such as when policymakers are vague about economic assumptions 
underpinning the budget, or when they resort to creative accounting and off-budget financing schemes (von Hagen, 2010). Second, deficit bias can also arise from so-called "common pool" problems. Incumbents enhance their chances of re-election by maximising the marginal benefits of public goods or services (or tax breaks) to their own constituents without internalising to these same constituents the full marginal costs of those commitments. The "common pool" problem is especially problematic to discipline overall fiscal policy when decentralised fiscal entities can partake in free-rider behaviour, neglecting the impact on the aggregate fiscal position. ${ }^{2}$ A third potential cause of deficit and pro-cyclicality bias is the well-known problem of time-inconsistency (Alesina and Tabellini, 1990), whereby stated ex ante policy positions (typically consistent with the national interest) are conveniently considered by policymakers to be less desirable ex post, when electoral and regional interests dominate. Problems of time inconsistency can also arise when a government saddles a successor (and possible rival) government with a larger debt burden, leaving it less fiscal "space" than otherwise to sustain existing programmes.

In theory, given sufficient transparency, financial markets ought to provide sanctions that are adequate to discourage fiscal indiscipline due to misguided discretion, through several channels (Debrun et al, 2009). First, prospectively higher deficits would signal an increased risk that these would be monetised, raising inflation expectations and long-term interest rates, reducing policymakers' likely options for politically motivated fiscal initiatives. This effect could be further strengthened if credit spreads on public debt increase due to higher perceived risks of default. Second, policymakers may gradually fear the country's rising public debt is approaching a "tipping point," with politically costly near-term adverse effects on economic growth. ${ }^{3}$ The evidence, however, is mixed on the extent to which financial markets effectively discipline fiscal profligacy. As a general rule, they tend to react with some delay. ${ }^{4}$

\section{Institutional Remedies}

Institutional reforms are thought to hold the promise of modifying the decision calculus of policymakers so as to improve the prospect that fiscal policy will remain supportive of macroeconomic stability. A number of different instruments and approaches can improve policymakers' incentives. One option is to require that fiscal commitments be made clear via fiscal targets set out in a medium-term fiscal framework, with implementation buttressed by procedural and transparency requirements spelled out in a fiscal responsibility law (Kumar and Ter-Minassian, 2007). New Zealand and Australia stand out in this context. Both committed, through legislation, to fiscal frameworks requiring that budgets take into account the long-term consequences of policies; when budgets depart from a prudent path, the government is obliged to explain how caution is to be restored to fiscal policy. The idea behind such legislation is to force future governments to have actually to repeal the law, which in turn could be politically costly.

Where political commitment is lacking or insufficiently strong, however, numerical fiscal rules may hold promise of constraining the perverse incentives noted earlier. ${ }^{5}$ Fiscal rules have gained popularity. In 1990 , only seven countries worldwide had a fiscal rule; by early 2009, either national or supranational rules were in place in 21 advanced economies, 33 emerging markets, and 26 low-income countries (IMF, 2009). Such rules can improve fiscal performance when backed by sufficient political commitment and a fully transparent fiscal process. There is evidence of a positive link between the quality of numerical fiscal

2. This can pose a particular problem in monetary unions where the centralisation of monetary policy can reduce each member's incentive to maintain a disciplined fiscal stance (Beetsma and Bovenberg, 1999).

3. Reinhart and Rogoff (2009) find that public debt levels of 90\% of GDP and higher in industrialised economies are associated with noticeably lower rates of economic growth.

4. See Wachtel and Young (1987), Balassone et al. (2004), Engen and Hubbard (2004), and Gale and Orzag (2004).

5. See, for instance, Kopits and Symansky (1998) and Kopits (2001). 
rules and fiscal discipline (European Commission, 2005 and 2009; Guichard et al., 2007; and IMF 2009). At the same time, numerical fiscal rules suffer from several weaknesses. First, unless carefully constructed, rules can in some circumstances (e.g., simple deficit and debt ceilings) result in pro-cyclicality (IMF, 2004). Second, rules can be harmful to the quality of public finances through inadvisable compositional effects when, for instance, pro-growth public investment is cut to respect an expenditure cap (Blanchard and Giavazzi, 2004). Third, where political will is lacking, rules can motivate creative accounting and offbudget operations, undermining transparency and, ultimately, democratic control over the budget (von Hagen and Wolff, 2006).

A third, and potentially complementary, option is the establishment of an independent fiscal body as a practical means of depoliticising fiscal policy. The principal purpose of creating such an entity is to reduce the possibility of government failure arising from the problems noted above, by delegating some aspects of fiscal policy to an unelected but accountable body. At one end of the conceptual spectrum are those that, similarly to central banks, would be mandated to achieve one or more politically agreed fiscal objectives (e.g., sustainability and/or output stabilisation), with delegated authority over requisite instruments (e.g., select taxes) but subject to appropriate accountability. At the other end are existing institutions with more circumscribed interventions in budget formulation or monitoring. Referring to the former institutions as independent fiscal authorities (IFA), and to the latter as fiscal councils (FC), Debrun et al. (2009) provide a useful typology of independent fiscal institutions according to the scope of their mandate and their modus operandi (Figure 3). ${ }^{6}$

Figure 3. Typology of fiscal agencies

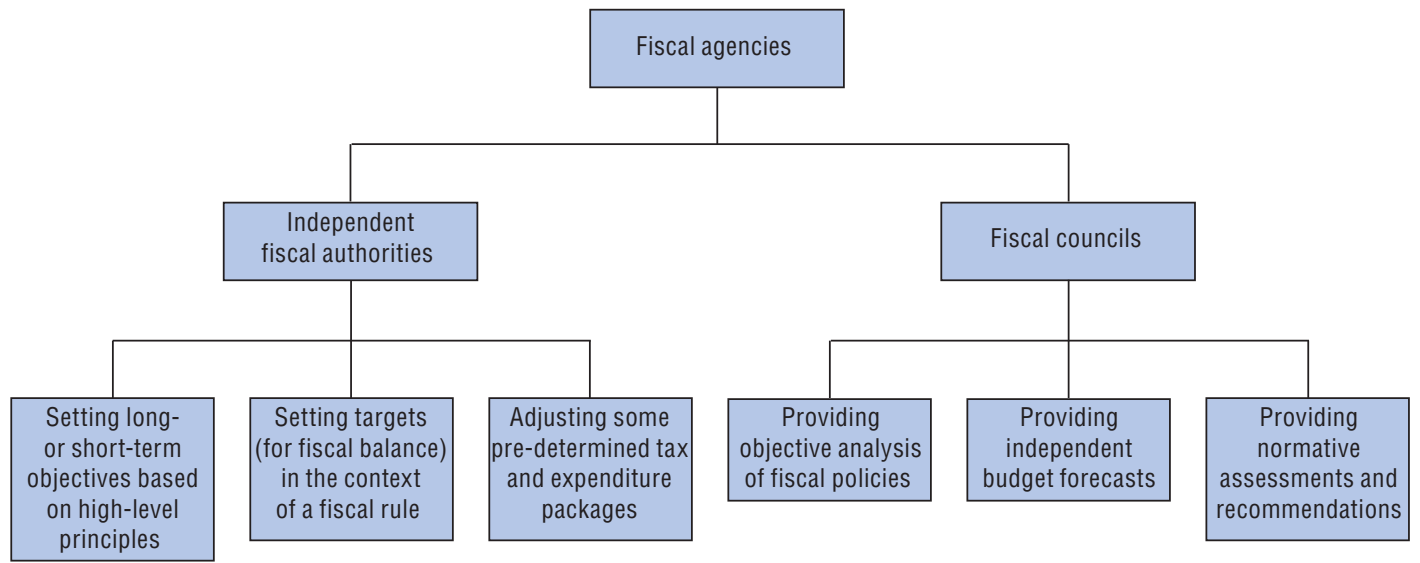

Source: Debrun, X., D. Hauner and M. S. Kumar (2009), "Independent fiscal agencies", Journal of Economic Surveys, 23(1), pp. 44-81.

\section{Independent Fiscal Authorities}

Substantial policy responsibility would be delegated to an IFA. Economic theory stresses four criteria necessary at a minimum for delegation of responsibility to non-elected officials to hold promise of achieving better outcomes (Alesina and Tabellini, 2007). First, policies formulated by elected officials should result in socially harmful distortions. Second, there should be broad agreement on what constitutes sound policies in the delegated area. Third, the delegated area of responsibility should have no distributional implications, as distributional issues should remain the responsibility of elected officials. Finally, delegation should enhance policy coordination. The delegation of monetary policy to independent monetary policy committees in central banks is widely seen as satisfying these four tests: the politicisation

6. Other terms are found in the literature. For instance, Wyplosz (2008) refers to an IFA as a "hard" fiscal policy council, as distinct form a "soft" or "very soft" council. 
of monetary policy can result in socially harmful inflation; there is broad consensus on what constitutes sound monetary policy; distributional issues are not the primary concern of the authorities; and coordination with fiscal policy is facilitated by the presence of a single authority.

Set against the above criteria, some advocates have argued that the delegation of the overall fiscal balance potentially fits within this decision framework. Deficit and pro-cyclical bias have socially harmful effects, there is reasonably broad agreement that deficits that threaten fiscal sustainability constitute unsound fiscal policy, the fiscal balance mostly has inter-generational impacts, and delegated responsibility for fiscal policy would make macroeconomic policy coordination easier. A host of proposals are found in the literature. ${ }^{7}$ These differ mostly according to the degree of autonomy that would be granted to the agency to set the objectives and targets for fiscal policy, and whether it would have partial control over one or another fiscal instrument, that is, spending or taxes. (A list of such proposals is available in Annex 1, drawn from Debrun et al. (2009)).

In contrast with monetary policy, however, at least one strong conceptual argument and a number of practical implementation challenges arise in respect of delegated fiscal policy responsibilities. Conceptually, and as Kopits (2007) has noted, an IFA "is nonviable because of the difficulty of defining unambiguously a principal-agent relationship at arm's length for the conduct of fiscal policy." There are also several implementation problems. First, whereas a pre-defined range of inflation is the usual objective of monetary policy, ${ }^{8}$ the twin objectives of fiscal policy - promoting stable economic growth and ensuring fiscal sustainability - can pose difficult conflicting policy challenges when there are uncertainties over the extent and appropriateness of discretionary counter-cyclical policy. Second, the target for monetary policy is usually a specific level of short-term interest rates or rate of growth of the money supply, which are straightforwardly measured and impacted with predictable lags. Finally, there tends to be fairly broad agreement on what constitutes an excessive rate of inflation. By contrast, consensus is lacking on what is an unsafe level of the fiscal deficit or the optimal level of public debt. As well, the instruments otherwise available to an independent fiscal agency - taxes and public expenditure - would, for distributional concerns, need to remain under the control of elected officials. ${ }^{9}$ Thus, and not surprisingly, no IFAs presently exist in the OECD. By contrast, delegation of selected aspects of fiscal policy to fiscal councils, together with appropriate accountability measures, is prevalent in a number of countries.

\section{Fiscal councils}

There are several ways in which an independent body, or fiscal council, with more circumscribed responsibilities can potentially contribute to improved fiscal performance. Broadly speaking, fiscal councils can help by limiting political influence over technical aspects of fiscal policy formulation (from either a positive or normative perspective) or monitoring. With respect to positive economic analysis, fiscal councils can intervene at any number of points in the policymaking process. They can be tasked with making independent macroeconomic forecasts, or providing assumptions or projections of key variables or parameters on which budget projections can be based. Indeed, as previously noted, an important source of deficit bias in practice is an overly optimistic macroeconomic scenario. Empirical evidence demonstrates that macroeconomic forecasts show no statistically significant bias when prepared by independent agencies, in contrast to forecasts in countries that rely on government agencies (Jonung and Larch, 2006; and Hallerberg et al., 2001). ${ }^{10}$ Fiscal councils can also be tasked with making independent revenue and

7. Debrun et al., (2007) refer to such entities as "independent fiscal authorities".

8. Although output stabilisation is occasionally an additional objective.

9. This is less pertinent for the overall levels of taxes and spending than for their structure.

10. This may be a greater concern in small countries with relatively fewer private institutions providing independent macro forecasts than in larger countries. 
expenditure projections, whether based on current or prospective policies. Revenue projections are particularly prone to politically self-interested upward bias, since these create the ex ante fiscal space for planning higher spending than otherwise advisable. ${ }^{11}$ Fiscal council assessments of long-run fiscal implications of tax and spending initiatives also can contribute to improving the transparency of budgetary decisions that are highly sensitive to demographic developments. In some instances, fiscal councils can be assigned a key role in monitoring fiscal performance under a politically agreed medium-term fiscal framework, including in some cases adherence to a numerical rule. Fiscal councils tasked with a mandate to undertake positive economic analysis play an indirect but potentially effective role in limiting politically motivated deficit-bias by improving transparency and helping to highlight the true cost of fiscal decisions.

Less than full delegation of fiscal policy does not, however, pre-empt assigning a normative role to an independent fiscal council. While final fiscal decisions are left to elected officials, a fiscal council's proposal regarding the appropriate stance of fiscal policy and a cautious budgetary path for securing sustainability can play a disciplining role by raising public pressure on officials. Where the government's credibility is particularly weak following a long period of poor fiscal performance, its commitment to a policy framework formulated on the basis of, or in concert with, the normative position of a fiscal council, can help garner public support. Indeed, broad agreement on the fiscal objective and a willingness of the government to fully integrate the fiscal council into the fiscal policymaking process are necessary preconditions for a fiscal council to be effective.

\section{(c) Implementation considerations}

Fiscal councils will vary across countries due to a large number of country-specific factors. These include the underlying causes of the fiscal indiscipline, the political landscape and the party structure, and the existing institutional budgetary arrangements and procedures. But whatever form it takes and the delegated responsibility it is assigned, four institutional features will predominate in all cases. First, the agency's mandate must satisfy several criteria. It should be unambiguous and achievable, and the delegated responsibility should have an economic rationale, such as to reduce deficit bias. Second, the agency needs to be assured of full discretion in carrying out the tasks necessary to fulfillment of the mandate. Third, accountability is critical; elected officials must be able, on behalf of voters, to conduct ex post evaluations to ensure that the delegated powers are in fact being used in pursuit of the agency's mission. Finally, independence from political influence requires adequate firewalls, both in the staffing of the agency and in the latter's everyday operations. Moreover, independence is not unrelated to the agency's funding. The level of public funding must obviously be commensurate with the scope of the agency's mission, and should be protected from politically motivated reductions, notwithstanding the difficulties of distinguishing the latter from other apparent reasons.

\section{Experience with fiscal councils}

Although fiscal councils remain more the exception than the rule throughout the world, their number is growing. The impetus to create new independent fiscal councils comes both from generally positive experiences in countries in which they have existed, and from increasing support among international organisations for such agencies. The scope of and for independent fiscal institutions has been of interest in the European Commission for some time (see, for instance, European Commission, 2006), and by staff of the IMF (see, for example, Annett et al, 2005; and Kumar and Ter-Minassian, 2007). Recommendations to consider such agencies have appeared in a number of recent OECD Economic Surveys.

11. This is not to say, however, that there are not countries in which the government, out of fiscal prudence, purposefully projects revenues conservatively at times. 


\section{ECO/WKP(2010)85}

While stocktaking of fiscal councils is complicated by the variety of agencies that fit the generic definition of a fiscal council, most in OECD countries tend to fall into three non-exclusive categories. ${ }^{12} \mathrm{~A}$ first set includes bodies that provide independent forecasts used in the formulation of the budget, or against which the official projections are, or can be, assessed. Also included in this group are entities that assess fiscal policy issues using positive rather than normative analysis such as assessing cyclical impacts on the budget or the fiscal implications of budgetary programs (e.g., the medium- and long-term costs of a health care reform). A second group includes councils that are tasked with providing independent forecasts of macroeconomic and budgetary variables needed for the elaboration of the annual budget. A third category comprises entities with a mandate to provide normative views on the appropriateness of the overall stance of fiscal policy from, say, a cyclical perspective, or the desirable time line to restore fiscal sustainability. Existing institutions include hybrids of these, however, that combine independent macroeconomic and budgetary projections with a mandate to assess performance relative to prior commitments to a mediumterm fiscal framework or a numerical rule. Table 1 lists a number of independent fiscal institutions in the EU members of the OECD, together with an enumeration of their tasks. The table shows independent institutions and their characteristics as given by the European Commission's 2005 and 2008 surveys of EU member countries regarding fiscal institutions (European Commission, 2006; European Commission, 2009), augmented by the Fiscal Council of Hungary and the UK Office of Budget Responsibility (OBR). The existence of an institution within the terms of this exercise does not imply that it has either a wide or ex ante mandate, or that it is effective in carrying out this role. Fiscal councils in a number of other OECD countries are discussed below. ${ }^{13}$

12. Some have suggested that international organisations themselves, such as the IMF, OECD, and European Commission, also play a role as quasi-independent institutions, since their macroeconomic and fiscal analyses and policy prescriptions are in principle unaffected by purely political considerations. At the same time, none of these has either the resources or the detailed country-specific knowledge needed to undertake the adequate and real-time analysis needed for thorough fiscal oversight (Kopits, 2010).

13. Fiscal councils in non-EU OECD countries are not included in the table because of the absence of information on these entities collected from a similar questionnaire as used by the European Commission. Inclusion of the Fiscal Council of Hungary (which commenced operations after the European Commission's 2008 survey) in the table has been done in consultation with the Fiscal Council of Hungary. 
Table 1. List of Independent Institutions Considered in EC Study

ECO/WKP(2010)85

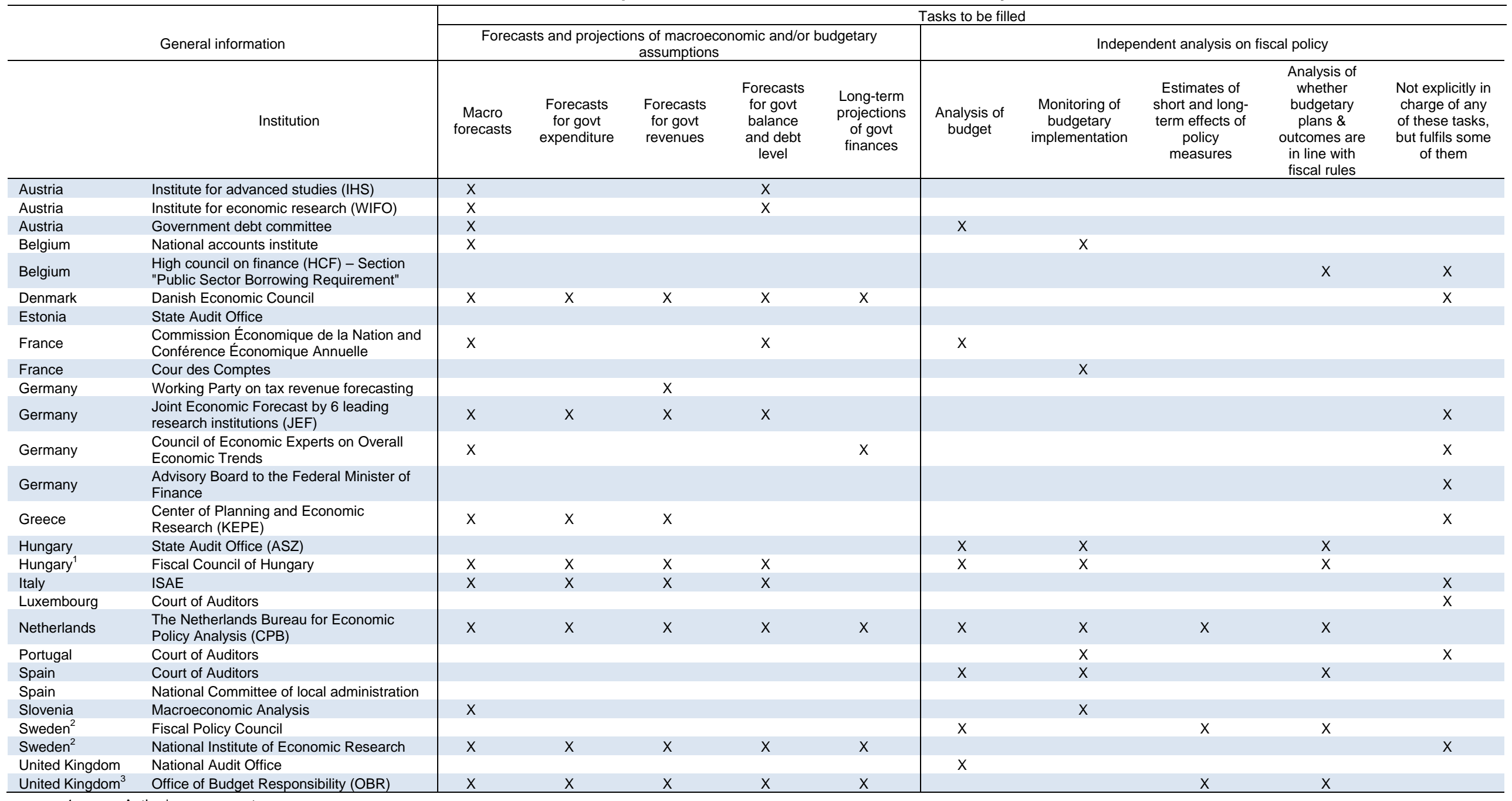
1. Author's assessment.

2. Author's assessment. The mandate includes monitoring and evaluating the quality of the government's economic forecasts and underlying models. The National Institute of Economic Research also undertakes analysis of whether budgetary plans and outcomes are in line with fiscal rules.

Source: "National independent institutions", Chapter III, Public Finances in EMU, 2006, except where noted. 
Table 1. List of Independent Institutions Considered in EC Study (cont.)

\begin{tabular}{|c|c|c|c|c|c|c|c|c|}
\hline \multirow{2}{*}{\multicolumn{2}{|c|}{$\begin{array}{l}\text { General information } \\
\text { Institution }\end{array}$}} & \multicolumn{7}{|c|}{ Normative reports and/or recommendations on fiscal policy } \\
\hline & & $\begin{array}{c}\text { Normative } \\
\text { statements in } \\
\text { budgetary plans } \\
\text { and respect of } \\
\text { the fiscal policy } \\
\text { rules } \\
\end{array}$ & $\begin{array}{c}\text { Assessment of the } \\
\text { budget/alternative } \\
\text { quantification of } \\
\text { the measures } \\
\text { therein }\end{array}$ & $\begin{array}{l}\text { Proposals for } \\
\text { changes in the } \\
\text { budgetary plans }\end{array}$ & $\begin{array}{c}\text { Normative } \\
\text { statements on } \\
\text { implementation } \\
\text { of fiscal } \\
\text { plans/respire of } \\
\text { fiscal rules } \\
\end{array}$ & $\begin{array}{l}\text { Alert function to } \\
\text { signal a possible } \\
\text { deviation from } \\
\text { plans }\end{array}$ & $\begin{array}{l}\text { Recommendation } \\
\text { in case a slippage } \\
\text { to initial fiscal } \\
\text { plans is identified }\end{array}$ & Others \\
\hline $\begin{array}{l}\text { Austria } \\
\text { Austria }\end{array}$ & $\begin{array}{l}\text { Institute for advanced studies (IHS) } \\
\text { Institute for economic research (WIFO) }\end{array}$ & & & & & & & \\
\hline $\begin{array}{l}\text { Austria } \\
\text { Austria }\end{array}$ & Institute for economic research (WIFO) & & & & & & & \\
\hline $\begin{array}{l}\text { Austria } \\
\text { Belgium }\end{array}$ & $\begin{array}{l}\text { Government debt committee } \\
\text { National accounts institute }\end{array}$ & & & $\mathrm{x}$ & & & & \\
\hline Belgium & National accounts institute & & & & & & & \\
\hline Belgium & $\begin{array}{l}\text { High council on finance (HCF) - Section } \\
\text { "Public Sector Borrowing Requirement" }\end{array}$ & & & $x$ & $\mathrm{x}$ & $\mathrm{x}$ & $\mathrm{x}$ & \\
\hline Denmark & Danish Economic Council & & & $\begin{array}{r}X \\
\text { (Federated } \\
\text { entities) }\end{array}$ & $\mathrm{x}$ & $\mathrm{x}$ & $\mathrm{x}$ & \\
\hline Estonia & State Audit Office & & & & $\mathrm{x}$ & $\mathrm{x}$ & $\mathrm{x}$ & \\
\hline France & $\begin{array}{l}\text { Commission Économique de la Nation } \\
\text { and Conférence Économique Annuelle }\end{array}$ & & & & & & & \\
\hline France & Cour des Comptes & & & & $\mathrm{x}$ & & & \\
\hline Germany & Working Party on tax revenue forecasting & & & & & & & \\
\hline Germany & $\begin{array}{l}\text { Joint Economic Forecast by } 6 \text { leading } \\
\text { research institutions (JEF) }\end{array}$ & & & & & & $\mathrm{x}$ & $\mathrm{x}$ \\
\hline Germany & $\begin{array}{l}\text { Council of Economic Experts on Overall } \\
\text { Economic Trends }\end{array}$ & & & & & & $\mathrm{x}$ & \\
\hline Germany & $\begin{array}{l}\text { Advisory Board to the Federal Minister of } \\
\text { Finance }\end{array}$ & & & & & & & $\mathrm{x}$ \\
\hline Greece & $\begin{array}{l}\text { Center of Planning and Economic } \\
\text { Research (KEPE) }\end{array}$ & & & & & & & \\
\hline Hungary & State Audit Office (ASZ) & & $\mathrm{x}$ & & $\mathrm{x}$ & & & \\
\hline Hungary ${ }^{1}$ & Fiscal Council of Hungary & & $x$ & $\mathrm{x}$ & $\mathrm{x}$ & $\mathrm{x}$ & $\mathrm{x}$ & \\
\hline Italy & ISAE & & & & & & & \\
\hline Luxembourg & Court of Auditors & & $\mathrm{x}$ & & & $\mathrm{x}$ & $\mathrm{x}$ & \\
\hline Netherlands & $\begin{array}{l}\text { The Netherlands Bureau for Economic } \\
\text { Policy Analysis (CPB) }\end{array}$ & & & & & & & \\
\hline Portugal & Court of Auditors & $\mathrm{x}$ & & & $\mathrm{x}$ & & & \\
\hline Spain & Court of Auditors & & & & $\mathrm{x}$ & & & \\
\hline Spain & $\begin{array}{l}\text { National Committee of local } \\
\text { administration }\end{array}$ & & $\begin{array}{r}\text { Only local } \\
\text { finances }\end{array}$ & & & & & \\
\hline Slovenia & Macroeconomic Analysis & & & & & & & \\
\hline Sweden ${ }^{2}$ & Fiscal Policy Council & $\mathrm{x}$ & & & & $\mathrm{x}$ & $\mathrm{x}$ & \\
\hline Sweden $^{2}$ & National Institute of Economic Research & $\mathrm{x}$ & & & $\mathrm{x}$ & & & \\
\hline United Kingdom & National Audit Office & $x$ & & & & & & $\mathrm{x}$ \\
\hline United Kingdom $^{3}$ & Office of Budget Responsibility (OBR) & $\mathrm{x}$ & & & & $\mathrm{x}$ & & \\
\hline
\end{tabular}




\section{(a) Fiscal councils with a normative mandate}

Countries have benefited from the presence of fiscal councils to which normative assessments have been delegated. Throughout the OECD, especially in the European Union, the mandates of a number of different types of independent fiscal institutions include the possibility or requirement to take normative positions on various aspects of fiscal policy. Such institutions can include advisory bodies, independent research institutions, and some state audit offices. Where such institutions tend to be most effective is when they are formally integrated into the fiscal policy formulation and monitoring process, and when the government is required to consider the recommendations made by the agency. Several such institutions stand out in the OECD area.

In Austria, the Government Debt Committee (GDC) has a mandate to regularly assess the sustainability of fiscal policy, taking into account macroeconomic circumstances, with a particular focus on the outlook for debt sustainability and the quality of public finances. Its twelve members are public finance experts nominated by the federal government, social partner organisations, and representative bodies of Austrian communities, cities and states (the latter do not have voting right). It receives funding and staffing from the Austrian National Bank. The GDC disseminates to the public its annual report that contains recommendations made to the government via the Minister of Finance.

Belgium's High Council on Finance (HCF) is an advisory body formed initially in 1936 but strengthened in 1989 to help promote budget coordination and fiscal discipline in Belgium's federal system, and to contribute to the design and implementation of fiscal policy. ${ }^{14}$ While the HCF has several tasks, including making long-run ageing-related expenditure projections and providing regular assessments of various aspects of fiscal policy, its most vital role is normative insofar as it is charged with recommending the budget targets for the general government and its subsectors that are consistent with the borrowing requirement implied by the Stability Programme and expected ageing costs.

The Fiscal Council in Hungary was established in 2009 on legislation enacted in 2008 (the Law on Fiscal Responsibility). The legislation and creation of the Fiscal Council are part of a rules-based fiscal policy framework. The special mandate handed to the Fiscal Council is to help restore sustainability of fiscal policy and to promote fiscal transparency. Its tasks include making macroeconomic forecasts and projections for key budgetary variables, which serve as the baseline for the annual budget. In addition to biannual medium-term baseline (current legislation) projections, it also prepares macro-fiscal projections that incorporate the effects of each budget bill in time for legislative action. The Council also makes methodological suggestions for fiscal policy planning, and comments on the budget bill and other legislation with fiscal impacts. As part of this assignment, it costs all significant tax and expenditure proposals. Importantly, the Fiscal Council monitors compliance with Hungary's fiscal rules (including the pay-go rule and the debt limit requirement), but relies on dissuasive methods - through pressure from the public and financial markets - rather than coercion. On balance, the council has been able to carry out its mandate, although these are early days in the council's existence (Kopits and Romhanyi, 2010).

In Denmark, the Economic Council is an advisory body that not only provides macroeconomic forecasts but also undertakes analyses of a variety of fiscal policy issues related to the functioning of the public sector, the tax system, fiscal sustainability and the fiscal stance, on the basis of which it issues policy recommendations. The council is also charged with monitoring compliance with current fiscal rules, issuing recommendations as needed to ensure compliance.

14. The National Accounts Institute (NAI) also plays a significant independent role in Belgium, since it provides macroeconomic forecasts. 
In 2007, Sweden created the Fiscal Policy Council with a mandate to assess the extent to which the government achieves its policy objectives of long-run sustainability, a surplus target, a ceiling on central government spending, and a fiscal stance consistent with the cycle), and to monitor and evaluate the transparency of the budget and the quality of the government's economic forecasts.

Overall, these fiscal councils are considered to have been relatively effective in improving fiscal performance. Recommendations tend to be taken seriously, with governments adhering to them in many cases, even if reluctantly on occasion. For instance, in Sweden, the Fiscal Policy Council's first major challenge arose in relation to one of Sweden's fiscal policy objectives: ensuring an appropriate cyclical stance of policy. Despite strong resistance from the government, the council eventually prevailed in promoting the larger fiscal impulse it deemed warranted following the onset of the recent worldwide financial crisis. ${ }^{15}$ Several assessments (Debrun et al., 2009; Lebrun, 2006; and Coene, 2010) point to the HCF in Belgium as having been highly effective in achieving disciplined fiscal policy during the 1990s. At the same time, these studies also consider that the drive for euro adoption is likely to have played a powerful disciplining influence in Belgium, pointing to the lesser influence of the fiscal institutions during the post-euro adoption period than before. Debrun et al. (2009) attribute a large part of the effectiveness of the fiscal councils in Belgium, Denmark and Sweden to a strong social consensus and political will to stabilise and consolidate fiscal policy. Against a backdrop of historically low political will for fiscal prudence in Hungary, the presence of the new fiscal council there should, over time, provide some additional anecdotal evidence regarding the direction of causation noted earlier.

\section{(b) Fiscal councils providing independent analysis of fiscal issues}

Fiscal councils that provide independent analyses of fiscal issues play an important role in informing the government and the public about the budgetary implications of select policy issues. The next paragraphs elaborate the mandates and setups of several.

In the United States, the Congressional Budget Office (CBO) was established in 1975 to provide Congress with independent analyses of the costs and long-term effects of budget proposals. Its mission is to provide "...objective, nonpartisan, and timely analyses to aid in economic and budgetary decisions on the wide array of programs covered by the federal budget, and the information and estimates required for the Congressional budget process." The CBO produces a considerable number of reports each year, and regularly testifies before Congress. Its work is non-partisan, and the director is appointed without regard to political affiliation and solely on the basis of his/her fitness to perform the duties for a four-year term (even when the balance of power in Congress switches). The CBO's reputation for credible and impartial analysis has helped it become a central player in the annual budgeting process and in budget monitoring (Blöndal et al., 2003). Among the CBO's most important contributions to the annual budget process is the preparation of its baseline against which are assessed budget proposals, including the President's. The CBO's baseline, however, is constrained by the legal requirement that it be based on current law rather than the most likely policy scenario. While its analyses can focus on the impacts of any fiscal proposal, the $\mathrm{CBO}$ conducts only positive analysis; the agency does not engage in policy prescription.

The Canadian Parliament enacted in 2006 the Federal Accountability Act (FAA). Among other things, the FAA established the Parliamentary Budget Officer (PBO), modeled on the U.S. Congressional Budget Office. The mandate of the PBO is to provide the legislature objective analysis of the nation's finances, the government's estimates, and trends in the economy and, upon request by a committee or parliamentarian, estimates of the cost of any proposal for matters over which the Parliament has jurisdiction. As a Governor-in-Council appointment, the PBO serves "at pleasure." In turn, the PBO can be dismissed

15. This characterisation of effectiveness has to be seen from the perspective of the Fiscal Policy Council's mandate, which includes advising on the appropriate stance of fiscal policy. 
without cause by the Prime Minister, which potentially weakens the agency's political independence. The FAA provides for free and timely access to government data and information needed to fulfill the PBO's mandate. The PBO promotes value by relying on assistance from experts, accountability through dissemination of its products and through public debate, and non-partisanship by operating in an open and transparent manner. Experience during its first years of operation highlight the importance of having a clear mandate and a secure budget (Box 1).

\section{Box 1. Canada's Parliamentary Budget Officer.}

Following parliamentarians' frustrations over persistent Department of Finance under-projection of budget deficits during the 1980s and of surpluses during the 1990s, and recognising the Parliament's lack of technical expertise in accurately estimating the costs of large-scale federal projects, the Canadian Parliament enacted in 2006 the Federal Accountability Act (FAA). The FAA is aimed at addressing issues of conflict of interest, restrictions on election financing, improving administrative transparency, oversight and accountability. Among other offices also created by the FAA, the legislation established the Parliamentary Budget Officer (PBO), modeled on the U.S. Congressional Budget Office. The PBO began operations in 2008. The PBO is an officer of the Library of Parliament, and holds office for a renewable period of not more than 5 years. The mandate of the PBO is to provide the legislature objective analysis of the nation's finances, the government estimates and trends in the economy, and, upon request by a committee or parliamentarian, to estimate the cost of any proposal for matters over which the Parliament has jurisdiction. As a Governor-in-Council appointment, the PBO serves "at pleasure." In turn, the PBO can be dismissed without cause by the Prime Minister, which weakens the agency's political independence. The FAA provides for free and timely access to government data and information needed to fulfill the PBO's mandate.

The PBO uses an open and transparent operating model that promotes value by relying on assistance from experts, accountability through dissemination of its products and through public debate, and non-partisanship by operating in an open and transparent manner. There are two divisions. The Economic and Fiscal Analysis Division is responsible for analysis of economic trends and public finances. The division is staffed with professional economists experienced with the working environment and models at the Department of Finance, the Bank of Canada and the Canadian Revenue Agency. The Revenue and Expenditure Analysis Division is responsible for costing proposals and budgetary estimates.

During its first years of operation, the PBO encountered a number of parliamentary and government challenges to its interpretation of its mandate following the release of its first two reports. The first was the PBO's analysis of the fiscal impact of Canada's Afghanistan involvement, whose dissemination, albeit expected from the outset, was challenged by the parliamentarians who considered, despite ex ante agreement to its release, that the report should have been submitted first to Parliament on a confidential basis. The second release was of the PBO's first economic and fiscal outlook highlighting a projected recession in 2009 and the first deficit in a decade. Political displeasure with both releases resulted in a withholding of increased budgetary resources for the PBO, only to be reversed in the 20102011 Budget.

Experience during the early years of the PBO points to the need for several reforms going forward. These include: (i) making the PBO a fully independent authority appointed by the Parliament and serving during good behaviour rather than at pleasure; (ii) transparency is best assured if its principle and the release of analysis are enshrined in legislation; and (iii) resources need to be commensurate with the mandate (Page, 2010).

In Korea, the National Assembly Budget Office (NABO), established in 2003, provides fiscal policy advice to Parliament. The NABO's mission is to provide the national assembly with objective, nonpartisan analysis of the annual draft budgets, evaluate general fiscal policies and national programmes, undertake economic and revenue forecasts, and undertake general research. The Director is appointed by the Speaker of the National Assembly on consent of the Steering Committee. His or her term is not fixed, and dismissal can be at the discretion of the Speaker, on approval of the Steering Committee, which, $a$ priori, limits political independence. 
Mexico's Center for the Study of Public Finances is modeled on the CBO in the US, and is attached to Congress. Its mandate includes reviewing the periodical government reports on economic developments, the public finances and public debt, budget proposals and fiscal laws.

The Netherlands' Central Planning Bureau (CPB) is a major source of objective and independent analysis and forecasting. Since its inception in 1945, it has gained considerable respect for its independence and expertise. Significantly, it is well integrated into the annual budget process, providing the underlying macro forecast on which the budget is based (Box 2). The agency also undertakes analysis of a wide range of self-initiated topics, including on fiscal policy and labour issues, cost benefit analysis, and long-term budgetary issues. CPB also plays a special role as consensus-builder by evaluating the economic programmes of all political parties using a similar methodology and macro framework.

\section{Box 2. The Central Planning Bureau of the Netherlands}

Established in 1945, the Central Planning Bureau (CPB) plays a prominent and visible role in the fiscal policy arena in the Netherlands. Its main responsibilities are to provide independent macroeconomic and budgetary forecasts, but its remit also includes analysis in a wide range of topics, including the welfare state, the labour market, regulation and international economics, among others. It also undertakes cost-benefit analysis of large-scale public projects, as well as long-run studies, such as on welfare and the environment and the impact of population ageing on Dutch public finances.

The CPB's main responsibility is to provide independent macroeconomic and budgetary forecasts, and the agency makes no normative recommendations. Its autumn forecast is coordinated with submission of the government's budget, and incorporates the estimated economic and budgetary impacts of proposed fiscal policy measures. Significantly, the CPB's activities and contributions to the preparation of the budget are not mandated, but have become routine practice. In fact, CPB plays a special role tailored to Dutch coalition politics insofar as all political parties submit their economic programmes to the CPB for assessment, which facilitates comparisons. Moreover, employers' and employees' organisations also rely on CPB forecasts for wage negotiations.

Although formally part of the central government, CPB early on gained, and has maintained, considerable independence. The agency's independence is attributable to a number of factors. First, its funding from public sources is both adequate and secure enough to provide the agency sufficient freedom to set its own research agenda. Second, its independence is maintained through a quid pro quo; its independence from political interference requires that the agency itself not interfere in the political debate (Bos and Teulings, 2010).

Transparency is given very high priority. The director regularly testifies before the Parliamentary Commission on Economic Affairs, and all CPB studies receive considerable media coverage and often spur public debate.

The CPB stands out as an institution that has over the decades become fully integrated into the policymaking process while retaining a solid reputation for professionalism and impartiality in its analysis. This aspect of the CPB is considered "best practice" by the IMF (IMF, 2006).

\section{(c) Fiscal councils providing macroeconomic or budgetary forecasts}

Independent macroeconomic forecasts and budgetary projections can help reduce bias in fiscal policy by eliminating politically motivated optimism. In some instances, the government is legally required to either incorporate the fiscal council's macroeconomic projections, or to justify not doing so, while in other countries the independent forecasts serve as a guideline. Given the interdependency of the budget and the macroeconomic outlook (i.e., the dependency of the macro forecast on fiscal policies), close interaction between the government and the forecasting agency is needed to ensure consistency. Several agencies in the OECD are notable for the role of their independent macroeconomic forecasts in fiscal policymaking:

- In Belgium, the Federal Planning Bureau (FPB), on behalf of the National Accounts Institute (NAI), prepares the macroeconomic forecasts that the government is legally required to use in the preparation of the budget. There is empirical evidence (see below) suggesting that the delegation 
of macro forecasting in Belgium has had a measurable impact in reducing this source of bias in fiscal policy.

- The Institute of Economic Research (WIFO) in Austria supplies short- and long-run macroeconomic projections, which, even though not legally mandated, normally underpin the government's budget.

- As noted, the Netherlands' Central Planning Bureau (CPB), among other tasks, prepares the macroeconomic forecasts that are in practice almost always adopted by the government in the preparation of the budget. The CPB also provides projections for the main budgetary aggregates based on its macro forecast.

- While macroeconomic projections for the budget in Chile remain the responsibility of the government, two independent advisory committees exist to provide unbiased projections of key inputs. The Advisory Committee for Trend GDP (ACTG) of the Ministry of Finance (MoF) is composed of 16 independent members selected by the MoF from local communities of macroeconomists. The projections of the rates of growth of capital, labour, and total factor productivity are averaged after elimination of the extreme projections. While it reserves discretion over the methodology for deriving the output gap, the MoF is legally required to use the ACTG's projections as inputs to the preparation of its macroeconomic outlook. The Advisory Committee for the Reference Copper Price (ACRCP) provides projections of copper prices. ${ }^{16}$ The ACRCP is composed of 12 independent persons drawn from among Chile's community of copper market experts. As in the case of the ACTG, the average of members' projections of the price of copper, after elimination of the extreme projections, is treated as the official outlook for copper prices over the medium term.

- In Germany, the Working Party on Tax Revenue Forecasting prepares revenue projections on which the budget is based, although these are perforce affected by the fact that they are always based on the macroeconomic forecasts prepared by the Government.

- In the United Kingdom, the Office of Budget Responsibility (OBR) was created in 2010 to make independent assessments of the public finances and the economy. Its mandate includes direct responsibility over the forecast, including key judgments that underpin official projections. Moreover, the OBR is to confirm the likelihood that the Government's policy is consistent with achieving the forward-looking mandate set by the Chancellor. Finally, the OBR has a role in assessing the public sector balance sheet, including analyses of the costs of ageing and public service pensions.

\section{(d) Assessing the effectiveness of fiscal councils}

Empirical evidence of the effectiveness of fiscal councils is of three sorts. First, country-specific experiences have been investigated for a number of countries. These perforce attempt to compare fiscal performance by using indicators before and after the existence of a fiscal council, or before and after a fundamental change. Second, the European Commission (2006) drew inferences and conclusions about effectiveness from responses to its questionnaire in conjunction with descriptive material and empirical studies. Third, using information collected by the European Commission's survey, Debrun and Kumar (2008) constructed a number of quantitative indicators that characterise the setup, independence and

16. A third independent entity, the Advisory Financial Committee for Fiscal Responsibility Funds (AFCFRF), advises on the investment strategy of Chile's main sovereign wealth fund. 
desired influence of fiscal councils, which they use to gauge the impact of fiscal councils on fiscal discipline.

\section{Country specific studies}

\section{Belgium}

Belgium is a useful case for assessing the possible effectiveness of fiscal councils, given the strong mandate handed to the HCF, and the fact that the government is legally required to adopt the macroeconomic forecasts of the FPB. Indeed, the fiscal councils in Belgium have been purposefully given relatively strong mandates; Debrun and Kumar (2008) compute a comparatively high index of de jure influence for Belgium's fiscal councils. Belgium is also a good candidate because its experience with fiscal councils spans two decades of contrasting incentives emanating from the country's membership in the EU, with the 1990s dominated by policies to support euro adoption.

Two studies suggest that fiscal councils contributed to improved fiscal performance. While recognising the complexity of the exercise, Lebrun (2006) measures the extent to which reduced bias in macroeconomic forecasts prepared by the FPB (and used in budget formulation) via a decomposition of forecasting errors (specifically the mean square error) during the period 1994-2005 into the "bias proportion" (attributable to systematic over- or under-estimation), the variance proportion, and the covariance proportion. The very small values for the bias proportion provide strong evidence that "...FPB forecasts can be considered as unbiased." (Lebrun, 2006, p. 331) The author also painstakingly examines the reasons for which fiscal consolidation was stronger than already programmed throughout the period, and finds that growth surprises (i.e., higher GDP growth than on which the budgets were formulated) were not behind the better budgetary performance. In turn, discretionary policy actions must have contributed to better-than-expected outcomes. While cautioning that the roles of the fiscal councils need to be seen as complements to and not substitutes for political commitment, the author concludes that the reduced forecasting bias and the increased policy transparency arising from the strong coordinating role of the $\mathrm{HCF}$, which have helped the government resist pressures for higher spending, contributed to better performance. ${ }^{17}$

In a more recent study, Coene (2010) assesses the effectiveness of the HCF by constructing a synthetic annual index of effectiveness. ${ }^{18}$ Specifically, the index (values ranging from 0 to 5 , with the higher value suggesting greater impact) each year depends on answers to five questions answered through a careful review of the extent to which HCF recommendations impacted fiscal policy. These questions were: (i) Does each year's report contain a single clear recommendation for budget targets over the medium and long term? (ii) Is the recommendation consistent with previous ("vintage") recommendations? (iii) Does the recommendation simply mimic the government's Stability Programme? (iv) Has the recommendation been explicitly adopted by the government? and ( $v$ ) Have the recommended budgetary targets been met? Succinctly, "...the highest value for the indicator is reached in cases where the section elaborates a clear recommendation, that is not at odds with the section's previous views and is independent from - or, at least, cannot be tracked back to - government intentions and that is formally adopted and, ultimately, complied with by the government" ${ }^{\prime 9}$ (Coene, 2010, p. 14). While recognising the need for caution in interpreting the indicator (not least because of the substantial degree of expert judgment needed

17. More recently, however, the government was required, due to the inflexibility of the law, to use the somewhat dated macro projections of the FTB notwithstanding that these, due to rapidly changing economic circumstances, had become overly optimistic.

18. It should be noted that the author of the paper is a senior member of the HCF.

19. Here, "section" refers to the Public Sector Borrowing Requirement Section of the HCF. 
for its construction), the paper concludes that the HCF has been quite effective in promoting fiscal consolidation during the period 1990-1998. At the same time, the paper concludes that the section's effectiveness declined measurably during the next decade, which was likely due to the unusually strong political resolve during the 1990 s to achieve euro adoption.

\section{Chile}

Fiscal policy in Chile has largely remained conservative during the past two decades. This is reflected in a trend decline in gross and net central government debt and growth in net foreign assets. This good performance is attributable to several factors: sustained political commitment to prudent policy; the adoption of a fiscal rule and framework; and the enactment of a Fiscal Responsibility Law. Also present are the two independent advisory bodies (ACTG and ACRCH) that play a role in macroeconomic and budgetary forecasting without, however, having full responsibilities. The fiscal rule, in place since 2001, limits the growth of budgeted central government spending to an estimate of the growth of "structural" revenue, subject to achieving a targeted structural budget balance, which has remained set at a surplus of 1 percent of GDP. The over-riding objective is to ensure both fiscal sustainability and output stabilisation. As the rule focuses on a cyclically-adjusted budget balance, key determinants include the projected output gap and "structural" revenues. The former, of course, depends heavily on estimates of potential output, which in turn hinges on the growth of labour, capital and total factor productivity. Chile's revenue flows depend significantly on trend copper prices. In turn, the delegation of responsibility for projections of these key variables to non-partisan advisory bodies contributes to limiting potential forecasting bias. At the same time, the methodology itself for estimating the output gap remains the responsibility of the Ministry of Finance, which reserves a large margin for discretion. Schmidt-Hebbel (2010) has noted that backcasting of potential growth suggests that the output gap was likely over-estimated during 2001-2008, resulting in excessive spending and a pro-cyclical outcome. Over-estimates of trend copper prices also contributed to pro-cyclicality. Despite the legally binding projections from the two advisory bodies, the Government (Ministry of Finance) is left with substantial leeway to define the overall resource envelope.

\section{European Commission Survey}

The European Commission combined inferences from answers to select questions with descriptive analyses and selected studies in the literature in arriving at a number of conclusions about the potential effectiveness of independent fiscal institutions covered in its survey.

First, as previously noted, pro-cyclical bias arising from overly optimistic macroeconomic or budgetary forecasts can be reduced or eliminated by delegating responsibility to an independent agency. Second, fiscal councils are undertaking independent and self-initiated analyses of various fiscal policy issues or preparing forecasts report by a large majority having perceptible impact on the public's awareness and interest, through the media, and often trigger public debate. Third, while not controlling for a number of variables that could account for such differences, the Commission noted that fiscal performance (measured by several fiscal indicators) during the period 1995-2005 was superior in countries having at least one surveyed institution than in countries with none. Figure 4 shows the same indicators of fiscal performance over the same period as covered by the European Commission, but updated to take into account data revisions and extended to include non-EU OECD countries. 
Figure 4. Budgetary developments and fiscal councils ${ }^{1}$

1995-2005

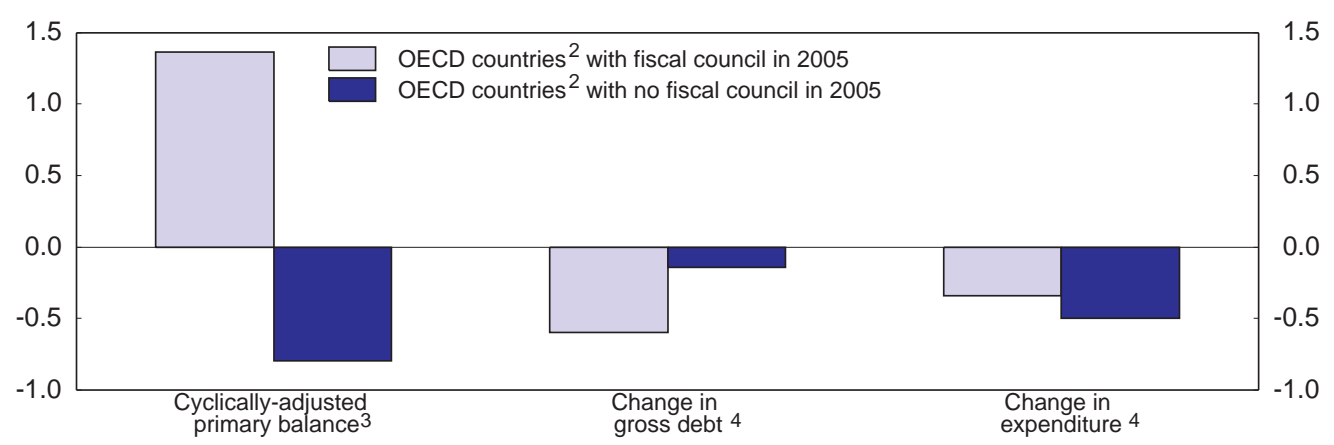

1. Fiscal councils as defined in EC (2009), Public Finances in EMU - 2009 and OECD calculations.

2. OECD countries excluding Chile, Mexico, Slovenia and Turkey.

3. Average balance over the period.

4. Average yearly change over the period.

Source: OECD, OECD Economic Outlook database.

\section{Cross-country evidence}

A pertinent empirical question is the extent to which fiscal councils, without delegated fiscal policymaking authority, have measurable influence on fiscal outcomes. Debrun and Kumar (2008) set out to investigate this question using the detailed information on the features of fiscal councils collected in the EC's survey of independent fiscal institutions. The authors constructed indices that characterise the set-up, independence and the potential influence of the agencies on the budgetary process, including via public debate. They use a weighting scheme that emphasises the agencies' role in preserving fiscal discipline, and in helping to implement rules where relevant. The authors' particular interest is in the channels through which the councils might have an impact. One premise is that the greater the degree of restraint exercised by the fiscal council or the greater the guarantee of independence from political interference, the greater the likelihood of perceived or actual impact on performance

The authors' results suggest that fiscal councils may indeed be influential. Their results are reproduced in Figure 5. There is a strong relationship between de jure influence exerted by a fiscal council and its perceived impact on fiscal performance, as well as between the perceived impact on fiscal performance and formal guarantees of independence. There is also a positive relationship between de jure influence and the guarantees of independence, which the authors interpret as suggesting "countries instituting such agencies seemed serious in their willingness to strengthen the council's effectiveness." (Debrun and Kumar, 2008, p. 490). At the same time, these results should be interpreted with caution given the heterogeneity of the independent fiscal bodies included in the data set. For instance, the data set includes state audit offices, most of which are tasked solely with ex post assessment of fiscal and budgetary performance, whereas a fiscal councils are expected to have an ex ante impact on fiscal policy formulation. 


\section{Figure 5. Potential channels of impact of fiscal councils and relationship between fiscal councils and fiscal} rules
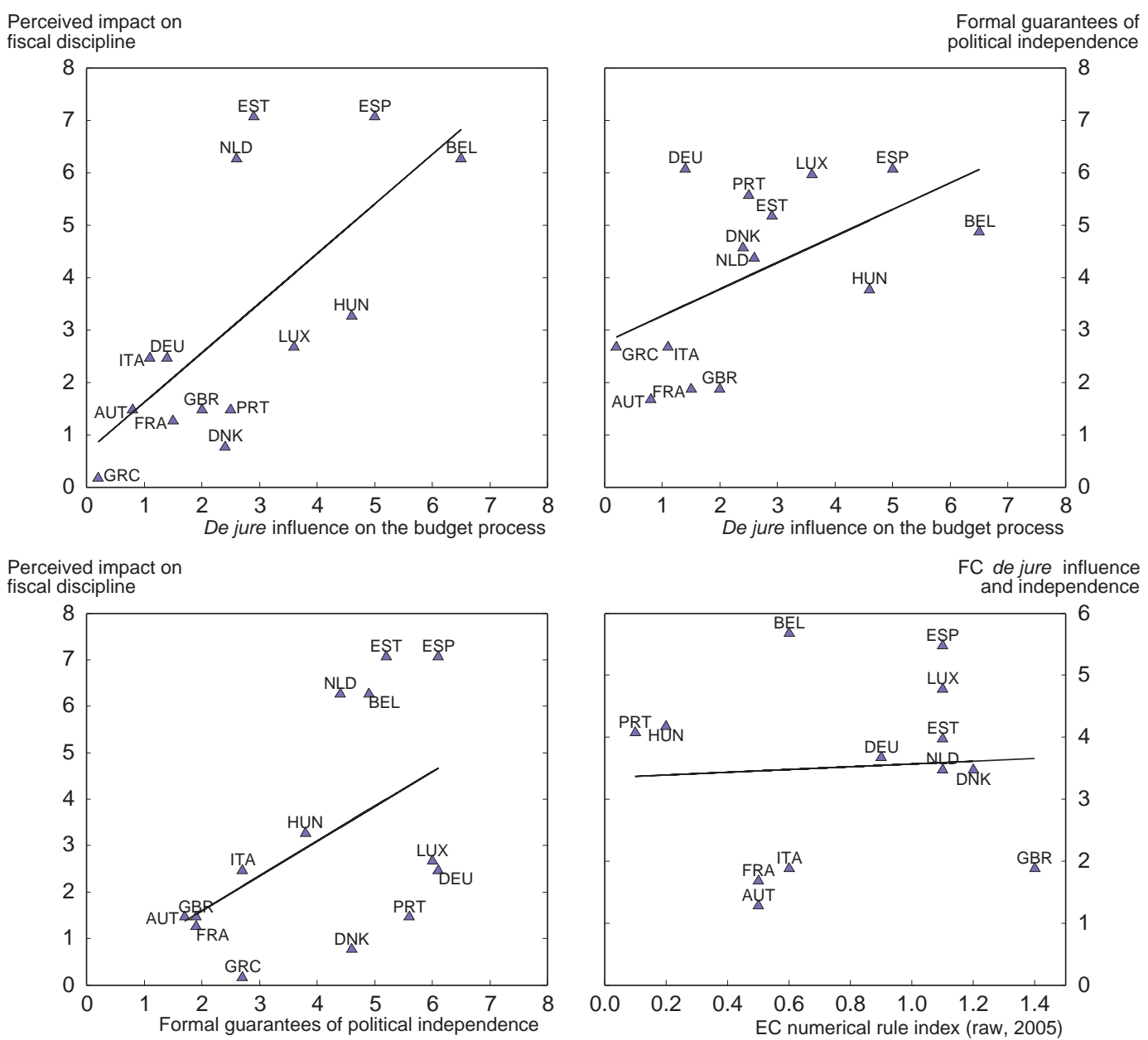

Source: Debrun, X. and M.S. Kumar (2008), "Fiscal Rules, Fiscal Councils and All That: Commitment Devices, Signaling Tools, or Smokescreen?", Proceedings of Banca d'Italia Public Finance Workshop, Roma.

\section{Conclusions}

This paper has attempted to provide an overview of the reasons for and experience with independent fiscal councils. Theoretical arguments for delegating some aspects of fiscal policy to independent institutions have become widely accepted. Deficit bias can become entrenched in fiscal systems plagued by inadequate transparency, which politicians can exploit in the pursuit of their own individual interests (viz., re-election) with insufficient regard for the average voter and the nation as a whole. As well, medium-term fiscal commitments can be breached through time-inconsistent policies that future governments find more convenient ex post than deemed appropriate ex ante. Institutional reforms, including all those that increase the transparency of fiscal policy formulation and implementation, are now widely seen as a necessary condition for restoring and sustaining fiscal discipline.

Some types of reform are more compelling than others. Where fiscal policy has remained unanchored by a medium-term focus and fiscal targets that can ensure growth promoting and sustainable fiscal stances, numerical rules can potentially play a helpful role. But experience has shown that rules can be easily breached, even as appearances may suggest otherwise for a while through creative accounting and offbudget transactions. In turn, there is growing advocacy for independent fiscal institutions to play a stronger 
policy role in helping to enhance both the transparency of policy in a number of ways, and in depoliticising key aspects of fiscal policy.

Totally depoliticizing fiscal policy via full delegation of responsibility for the fiscal balance is neither theoretically nor democratically advisable. There are at least two strong theoretical arguments against full delegation. First, there is considerable uncertainty regarding the optimal level of the deficit and debt, and consequently little hope for political consensus regarding the appropriate target to set. Second, fiscal policy in all respects has distributional consequences; deficits can redistribute to or from future generations, and within generations, depending upon the reasons for which debt is incurred. With accountability in democracies imposed through the ballot box, deferring full responsibility to technocrats in fiscal institutions would interfere with a fundamental right of the voter. Thus, while fiscal councils can in many instances be handed normative mandates - to offer views of what is technically deemed an appropriate fiscal stance - an illuminated legislature ought to remain the final arbiter.

At the same time, and well short of delegating full authority, independent fiscal councils can be assigned mandates that contribute to more disciplined fiscal policy. These include responsibility for, or contributions to, macroeconomic forecasting for the purposes of budget formulation, to reduce bias. These also include independent forecasts of key budgetary variables that can be prone to politically motivated bias, such as overly optimistic revenue projections (which creates fiscal "space" to boost unfunded spending) and under-projection of long-run costs of legislative initiatives. Given the complexities of many public programmes, and the associated challenges of understanding their impacts in terms of both efficiency and distribution, the general public can be well served by the funding of independent institutions mandated to undertake analysis of fiscal issues, simulate policy alternatives, make macroeconomic forecasts under different fiscal scenarios, etc. By informing politicians and the public about the larger implications of fiscal initiatives, a fiscal council can help pre-empt deficit bias arising from common pool problems. More informed voters are more able to hold politicians accountable, which in turn contributes to democratic decision-making.

Influence through such fiscal councils hinges on several factors. First, the agency must have full autonomy to establish its work priorities within the scope of its mandate. Second, there must be active and unfettered dissemination of the agency's analyses and reports. Indeed, surveys of fiscal councils throughout the EU reveal considerable conviction that dissemination and media support have visible impact on the debate over policy issues. Third, credibility is gained through sustained, high quality and visibly independent analyses (i.e., political feathers get ruffled occasionally) over long periods of time.

Experience and empirical evidence suggest that delegating macroeconomic forecasting to an independent fiscal council can indeed reduce forecasting bias and, therefore, the deficit bias that would otherwise follow. Given the intertwining of the macro economy and budget policy, the most effective delegation of economic forecasting will be obtained when there is close interaction between the government agency or agencies most responsible for budget formulation and the forecasting fiscal council, as in several countries, including Belgium and the Netherlands. While the forecasts of some agencies are binding (e.g., the FPB in Belgium), influence can also be achieved by lesser requirements, as in Germany where the government has to justify an alternative outlook from that of independent experts.

There is some empirical evidence that fiscal institutions can buttress a government's capacity to comply with a numerical rule. Such support can come through a range of activities to ensure compliance, including the preparation of baseline macro forecasts and a current services budget, and verifying adherence to transparency standards and best budgeting practices.

A key question surrounding the decision to create a fiscal council is why such an entity would have a potentially greater disciplining effect than existing unofficial and academic bodies or persons? In smaller 
countries with a relatively less developed infrastructure of unofficial bodies, the creation of a fiscal council enables the pooling of local expertise (creating analytical synergies) and access to financial and informational resources not otherwise available to unofficial bodies. In larger countries, however, where unofficial bodies are prevalent and potentially influential through the media and by active participation in public policy debates, a principal advantage gained from the creation of a fiscal council is the latter's access to the more detailed confidential data normally restricted to legislative and executive agencies. In all countries, however, a desired benefit to the government of creating an official fiscal council is to signal the government's commitment to good behaviour.

Good fiscal institutions are a necessary condition for achieving disciplined fiscal performance. Experience demonstrates, however, that their existence is not sufficient. Without strong and sustained political commitment to a medium-term fiscal goal and, where relevant, to the mandate of a fiscal council, durable improvements in fiscal performance will remain elusive.

\section{Bibliography}

Alesina, A., and G. Tabellini (1990), "A positive theory of fiscal deficits and government debt," Review of Economic Studies, 57: pp. 403-414.

Annett, A., J. Decressin and M. Deppler (2005), "Reforming the Stability and Growth Pact," IMF Policy Discussion Paper, 05/2, Washington, D.C.

Ayuso-i-Casals, J., S. Deroose, E. Flores and L.Moulin (2006), Policy Instruments for Sound Fiscal Policy, Palgrave-MacMillan.

Balassone, F., and M. S. Kumar (2007), "Cyclicality of fiscal policy,” in Kumar and Ter-Minassian, 2007.

Beetsma, R. M.W.J, and L. Bovenberg (1999), "Does monetary unification lead to excessive debt accumulation," Journal of Public Economics, 74:299-325.

Blanchard, O., and F. Giavazzi (2004), "Improving the SGP through a proper accounting of public investment”, CEPR Discussion Paper, No. 4220.

Blöndal, J.R., D.J Kraan and M. Ruffner (2003), "Budgeting in the United States," OECD Journal of Budgeting, 3: 7-54.

Bouthevillain, C., P. Cour-Thiman, G. van den Dool, P. Hernández de Cos, G. Langenus, M. Mohr, S. Momigliano, and M. Tujula, 2001, "Cyclically-Adjusted Budget Balances: An alternative approach,” ECB Working Paper, No. 77, Frankfurt: European Central Bank.

Bos, F., and C. Teulings (2010), "Lessons from the Netherlands," paper presented at the Conference on Independent Fiscal Institutions, Budapest, March 18-19.

Calmfors, L. (2003), "Fiscal policy to stabilise the domestic economy in the EMU," CESifo Economic Studies, 49: 319-353.

Calmfors, L. (2010), "Lessons from Sweden,” paper presented at the Conference on Independent Fiscal Institutions, Budapest, March 18-19. 
Coene, C. (2010), "Lessons from Belgium," paper presented at the Conference on Independent Fiscal Institutions, Budapest, March 18-19.

Debrun, X., and M. S. Kumar (2008), "Fiscal rules, fiscal councils and all that: commitment devices, signaling tools, or smokescreen?" Proceedings of Banca d'Italia Public Finace Workshop, Rome: Banca d'Italia.

Debrun, X., D. Hauner and M. S. Kumar (2009), "Independent fiscal agencies," Journal of Economic Surveys, 23(1): 44-81.

Engen, Eric M., and R. Glenn Hubbard. 2005. "Federal government debt and interest rates.” NBER Macroeconomics Annual, 19: 83-138.

European Commission (2006a), "Independent fiscal institutions in the EU member states," Public Finances in EMU-2006, Chapter 4, Brussels.

European Commission (2009), Public Finances in EMU—2009, Brussels.

Gale, W., and P. Orszag (2004), "Budget deficits, national saving and interest rates," Brookings Papers on Economic Activity, Washington, D.C.

Guichard, Stéphanie, Mike Kennedy, Echkard Wurzel and Christophe André (2007), "What promotes fiscal consolidation: OECD country experiences," OECD Economics Department Working Papers, No. 553, Paris.

von Hagen, J., and G. Wolff (2006), "What do deficits tell us about debt? Empirical evidence on creative accounting with fiscal rules," Journal of Banking and Finance, 30: 3259-3279.

von Hagen, J. (2010), "The scope and limits of fiscal councils," paper presented at the Conference on Independent Fiscal Councils, Budapest, March 18-19.

Hallerberg, M., R. Strauch, and J. von Hagen (2001), "The use and effectiveness of budgetary rules and norms in EU member states," Report of the Institute of European Integration Studies for the Dutch Ministry of Finance, June.

Heller, P. (2003), Who Will Pay, International Monetary Fund, Washington, D.C.

HM Treasury (2010), Draft: Charter for Budget Responsibility, November, London.

IMF (2004), World Economic Outlook, September, Washington D.C.

IMF (2006), "Report on the Observance of Standards and Codes Fiscal Transparency Module," IMF Country Report, No. 06/124, Washington, D.C.

International Monetary Fund (2009), "Fiscal Rules-Anchoring Expectations for Sustainable Public Finances," December.

Jonung, L. and M. Larch (2006), "Improving fiscal policy in the EU: the case for independent forecasts," Economic Policy, No. 21, pp. 491-534.

Kopits, G., and S. Symansky (1998), "Fiscal Policy Rules”, Occasional Paper, No. 162, International Monetary Fund, Washington, D.C.

Kopits, G. (2001), “Fiscal rules: useful policy framework or unnecessary ornament?” IMF Working Paper, No. $01 / 145$.

Kopits, G., and B. Romhnyi (2010), "Lessons from Hungary," paper presented at the Conference on Independent Fiscal Institutions, Budapest, March 18-19. 
Kopits, G. (2010, “Brussels Can’t Monitor 27 Budgets,” Wall Street Journal, Monday, October 11.

Kumar, M. S. and T. Ter-Minassian (2007), Promoting Fiscal Discipline, International Monetary Fund, Washington, D.C.

Lebrun, I. (2006), "Fiscal councils, independent forecasts, and the budgetary process: Lessons from the Belgian case," in Ayuso-i-Casals et al. (2006), Policy Instruments for Sound Fiscal Policy, Palgrave-MacMillan.

Milesi-Feretti, G.M. and M., K., (2004), "Fiscal adjustment in EU countries: a balance sheet approach," IMF Working Paper, 04/143.

Mühleisen, M, S. Danninger, S. Hauner, D. Krajnyák and B. Sutton (2005), "How do Canadian budget forecasts compare with those of other industrial countries?" IMF Working Paper, 05/66.

Page, K. (2010), "Lessons from Canada," paper presented at the Conference on Independent Fiscal Councils, Budapest, March 18-19.

Poterba, J. M., and J. von Hagen (1999), Fiscal Institutions and Fiscal Performance, National Bureau of Economic Research.

Persson, T., and L. E. O. Svensson (1989), "Why a stubborn conservative would run a deficit: Policy with time-inconsistent preferences," Quarterly Journal of Economics, 104(2): 325-46.

Reinhart, C., and K. Rogoff (2009), This Time is Different: Eight Centuries of Financial Folly, Princeton, N.J., Princeton Press.

Rogoff, K. (1990), “Equilibrium political budget cycles,” American Economic Review, 80:21-36.

Schmidt-Hebbel, K. (2010), "Lessons from Chile," paper presented at the Conference on Independent Fiscal Councils, Budapest, March 18-19.

Straunch, R., M. Hallerberg, and J. von Hagen (2004), "Budgetary forecasts in Europe- the track record of the stability and convergence programs," Working Paper, No. 304, European Central Bank.

Van den Noord, P. (2000), "The size of automatic stabilizers in the 1990s and beyond," OECD Economics Department Working Paper, No. 230, Paris: OECD.

Wachtel, P., and J. Young (1987), "Deficit announcements and interest rates." American Economic Review 77, No. 5, pp. 1007-12.

Wyplosz, L. (2005), "Fiscal policy: institutions versus rules," National Institute of Economic Review, No. 191, pp. 64-78. 
ECO/WKP(2010)85

\begin{tabular}{|c|c|c|c|c|}
\hline \multicolumn{5}{|c|}{ Annex 1. Proposals for 'Independent Fiscal Authorities' } \\
\hline Reference & Mandate & Instrument(s) & Structure & Accountability \\
\hline Ball (1996): New Zealand & $\begin{array}{l}\text { Enhance the } \\
\text { contribution of fiscal } \\
\text { policy to output } \\
\text { stabilization }\end{array}$ & $\begin{array}{l}\text { Adjust income tax rates across the } \\
\text { board, and give instructions to the } \\
\text { central bank }\end{array}$ & $\begin{array}{l}\text { Macroeconomic policy } \\
\text { committee' to include a senior } \\
\text { civil servant of the finance } \\
\text { ministry and the central bank } \\
\text { governor }\end{array}$ & Unspecified \\
\hline Blinder (1997): USA & $\begin{array}{l}\text { Simplify the tax } \\
\text { code and minimize } \\
\text { tax distortions }\end{array}$ & $\begin{array}{l}\text { Decide specific tax policy matters } \\
\text { delegated by the legislature } \\
\text { and/or design tax proposals to be } \\
\text { put to up-or-down vote. }\end{array}$ & Independent federal tax authority' & $\begin{array}{l}\text { Detailed explanations of } \\
\text { decisions and public } \\
\text { scrutiny of supporting } \\
\text { material }\end{array}$ \\
\hline Calmfors (2003): EU & $\begin{array}{l}\text { Enhance the } \\
\text { contribution of fiacl } \\
\text { policy to output } \\
\text { stabilization }\end{array}$ & $\begin{array}{l}\text { Model 1: Enforce budget balance } \\
\text { target pre-specified by } \\
\text { parliament. Model 2: Provide } \\
\text { stabilizing fiscal impulse by } \\
\text { varying certain tax and } \\
\text { expenditures established by } \\
\text { parliament }\end{array}$ & $\begin{array}{l}\text { Long-term, non-renewable } \\
\text { appointments of established } \\
\text { professionals by government }\end{array}$ & $\begin{array}{l}\text { Appointments subject to } \\
\text { parliamentary approval. } \\
\text { Ex post evaluation } \\
\text { (dismissal clause at } \\
\text { qualified majority of } \\
\text { parliament). Overriding } \\
\text { clause by qualified } \\
\text { majority of parliament. }\end{array}$ \\
\hline $\begin{array}{l}\text { Eichengree } \text { et al. (1999): } \\
\text { Latin America }\end{array}$ & $\begin{array}{l}\text { Preserve debt } \\
\text { sustainability and } \\
\text { prevent } \\
\text { procyclicality }\end{array}$ & $\begin{array}{l}\text { Set legally binding annual 'debt } \\
\text { change limits' (DCL), which can } \\
\text { be changed during the year. If } \\
\text { budget violates DCL, the council } \\
\text { can raise indirect taxes or freeze } \\
\text { spending plans at levels of the } \\
\text { previous budget. }\end{array}$ & $\begin{array}{l}\text { Members of 'national fiscal } \\
\text { council' appointed by government } \\
\text { for } 9 \text { years. Staggered } \\
\text { appointments. Supplemented by } \\
\text { professional staff and preparing } \\
\text { forecasts and analysis. }\end{array}$ & $\begin{array}{l}\text { Acccountable to } \\
\text { parliament. No agenda- } \\
\text { setting power. } \\
\text { Nominations subject to } \\
\text { parliamentary approval. }\end{array}$ \\
\hline $\begin{array}{l}\text { Gruen }(1997,2000) \text { : } \\
\text { Australia }\end{array}$ & $\begin{array}{l}\text { Enhance the } \\
\text { contribution of fiscal } \\
\text { policy to output } \\
\text { stabiization while } \\
\text { preserving debt } \\
\text { sustainability }\end{array}$ & $\begin{array}{l}\text { Vary tax rates across the board } \\
\text { (through a 'fiscal parameter'), at } \\
\text { short notice and without } \\
\text { involement of the legislature, but } \\
\text { only within strict pre-defined } \\
\text { bounds }\end{array}$ & Similar to cwentral banks & $\begin{array}{l}\text { Parliament can override } \\
\text { decisions under certain } \\
\text { conditions }\end{array}$ \\
\hline Seidman (2001): USA & $\begin{array}{l}\text { Enhance the } \\
\text { contribution of fiscal } \\
\text { policy to output } \\
\text { stabilization }\end{array}$ & $\begin{array}{l}\text { Implement periodic adjustments } \\
\text { in taxes and spending relative to } \\
\text { budget. Content of adjustment } \\
\text { package pre-determined by } \\
\text { legislature, while IFA decides } \\
\text { magnitude and timing }\end{array}$ & $\begin{array}{l}\text { Members of 'fiscal policy board' } \\
\text { would be appointed for long } \\
\text { tenures. Alternatively, the Federal } \\
\text { Reserve Board could also decide } \\
\text { on fiscal adjustments }\end{array}$ & $\begin{array}{l}\text { Legislature can override } \\
\text { the council's decisions }\end{array}$ \\
\hline $\begin{array}{l}\text { von Hagen and Harden } \\
\text { (1995): EU }\end{array}$ & $\begin{array}{l}\text { Preserve debt } \\
\text { sustainability }\end{array}$ & $\begin{array}{l}\text { Set legally binding annual 'debt } \\
\text { change limits' (DCL). If budget } \\
\text { violates DCL, the national debt } \\
\text { board can impose across the } \\
\text { board spending cuts }\end{array}$ & $\begin{array}{l}\text { National debt boards' appointed } \\
\text { by government based on a list } \\
\text { established by the board. Long } \\
\text { tenures and staggered } \\
\text { appointments }\end{array}$ & Accountable to parliament \\
\hline Wren-Lewis (2002): EU & $\begin{array}{l}\text { Enhance the } \\
\text { contribution of fiscal } \\
\text { policy to output } \\
\text { stabilization while } \\
\text { preserving debt } \\
\text { sustainability }\end{array}$ & $\begin{array}{l}\text { Vary specific tax rates (VAT, sales } \\
\text { tax) for a limited time period and } \\
\text { without the involvement of the } \\
\text { legislature }\end{array}$ & Unspecified & Unspecified \\
\hline Wyplosz (2005): EU & $\begin{array}{l}\text { Preserve debt } \\
\text { sustainability }\end{array}$ & $\begin{array}{l}\text { Enforce debt target pre-specified } \\
\text { by parliament by setting legally } \\
\text { binding annual budget balance } \\
\text { targets on the basis of forecasts } \\
\text { prepared by the council and } \\
\text { binding in budget process }\end{array}$ & $\begin{array}{l}\text { Members appointed by national } \\
\text { government for fixed ter. Long } \\
\text { tenures (longer than legislature). }\end{array}$ & Accountable to parliament \\
\hline Source: Debrun et al. $(20$ & & & & \\
\hline
\end{tabular}




\section{WORKING PAPERS}

The full series of Economics Department Working Papers can be consulted at www.oecd.org/eco/workingpapers/

828 Minimising risks from imbalances in European banking (December 2010) by Sebastian Barnes, Philip Lane and Artur Radziwill

827 Resolving and avoiding unsustainable imbalances (December 2010) by Sebastian Barnes

826 Current account imbalances in the euro area: a comparative perspective (December 2010) by Sebastian Barnes, Jeremy Lawson and Artur Radziwill

825. Does fiscal decentralisation strengthen social capital? Cross-country evidence and the experiences of Brazil and Indonesia (December 2010) by Luiz de Mello

824. Fiscal decentralisation and public investment: The experience of Latin America (December 2010) by Luiz de Mello

823. Product market regulation and competition in China (December 2010) by Paul Conway, Richard Herd, Thomas Chalaux, Ping He and Jianxun Yu

822. Reforming China's monetary policy framework to meet domestic objectives (December 2010) by Paul Conway, Richard Herd and Thomas Chalaux

821. Regulatory reforms to unlock long-term growth in Turkey (December 2010) by Rauf Gönenç and Łukasz Rawdanowicz

820. After the crisis: mitigating risks of macroeconomic instability in Turkey (December 2010) by Łukasz Rawdanowicz

819. The 2008-09 crisis in Turkey: performance, policy responses and challenges for sustaining the recovery

(December 2010) by Łukasz Rawdanowicz

818. Fiscal-consolidation strategies for Canadian governments (November 2010) by Yvan Guillemette

817. The land transport sector: policy and performance (November 2010) by Jan Persson and Daeho Song

816. A simple model of the relationship between productivity, saving and the current account (November 2010) by Jean-Marc Fournier, Isabell Koske

815. The impact of structural policies on saving, investment and current accounts (November 2010) by Clovis Kerdrain, Isabell Koske, Isabelle Wanner 
814. Towards a less distortive and more efficient tax system in Portugal (November 2010) by Alvaro Pina

813. Are global imbalances sustainable? Shedding further light on the causes of current account reversals

(November 2010) by Luiz de Mello, Pier Carlo Padoan, Linda Rousová

812. Turkey's improving integration with the global capital market: Impacts on risk premia and capital costs

(November 2010) by Rauf Gönenç, Saygin Şahinöz, Özge Tuncel

811. Trade linkages in the OECD trade system

(October 2010) by Jérôme Brézillon, Stéphanie Guichard and Dave Turner

810. Enhancing the effectiveness of social policies in Indonesia

(October 2010) by Margherita Comola and Luiz de Mello

809. Tackling the infrastructure challenge in Indonesia

(October 2010) by Mauro Pisu

808. Phasing out energy subsidies in Indonesia

(October 2010) by Annabelle Mourougane

807. Implementing cost-effective policies in the United States to mitigate climate change (October 2010) by David Carey

806. Restoring fiscal sustainability in the United States

(October 2010) by Patrick Lenain, Bob Hagemann and David Carey

805. Norway: Sustainable development: climate change and fisheries policies (September 2010) by Paul O'Brien

804. Netherlands: How the transport system can contribute to better economic and environmental outcomes

(September 2010) by Tomasz Koźluk

803. Public-private partnerships and investment in infrastructure

(September 2010) by Sónia Araújo and Douglas Sutherland

802. Sustaining the momentum of fiscal reform

(September 2010) by Colin Forthun and Robert Hagemann

801. The consequences of banking crises for public debt

(September 2010) by Davide Furceri and Aleksandra Zdzienicka

800. A simulation model of federal, provincial and territorial government accounts for the analysis of fiscal-consolidation strategies in Canada

(September 2010) by Yvan Guillemette

799. Product market regulation: extending the analysis beyond OECD countries

(October 2010) by Anita Wölfl, Isabelle Wanner, Oliver Röhn, Giuseppe Nicoletti 